IRA-International Journal of Technology \&

Engineering

ISSN 2455-4480; Vol.10, Issue 02 (February, 2018)

Pg. no. 12-22.

Institute of Research Advances

https://research-advances.org/index.php/IRAJTE

\title{
Detection of Changes in Land Use/ Land Cover Using Remote Sensing and GIS Techniques in Area East of the Nile Khartoum State-Sudan
}

\author{
Babiker, E.M.A ${ }^{1}$, Ibrahim, M.M ${ }^{1 \#}$, Elhag, A.M.H ${ }^{2}$, Nser, S.H ${ }^{1}$, Elsheikh, M.A ${ }^{1}$, Dafaalla, \\ M.S ${ }^{1}$, Ibrahim, I.S \\ ${ }^{1}$ Department of Soil and Environment Sciences, Faculty of Agriculture University of Khartoum, Sudan. \\ ${ }^{2}$ Department of Basic Science, College of Natural Resources and Environmental Studies, University of \\ Bahri, Sudan.
}

\#corresponding author.

Type of Review: Peer Reviewed.

DOI: http://dx.doi.org/10.21013/jte.v10.n2.p1

\section{How to cite this paper:}

Babiker, E.M.A., Ibrahim, M.M., Elhag, A.M.H., Nser, S.H., Elsheikh, M.A., Dafaalla, M.S., Ibrahim, I.S. (2018). Detection of Changes in Land Use/ Land Cover Using Remote Sensing and GIS Techniques in Area East of the Nile Khartoum State-Sudan. IRA International Journal of Technology \& Engineering (ISSN 2455-4480), 10(2), 12-22. doi:http://dx.doi.org/10.21013/jte.v10.n2.p1

(C) Institute of Research Advances.

\section{(cc) BY-NC}

This work is licensed under a Creative Commons Attribution-Non Commercial 4.0 International License subject to proper citation to the publication source of the work.

Disclaimer: The scholarly papers as reviewed and published by the Institute of Research Advances (IRA) are the views and opinions of their respective authors and are not the views or opinions of the IRA. The IRA disclaims of any harm or loss caused due to the published content to any party.

Institute of Research Advances is an institutional publisher member of Publishers Inter Linking Association Inc. (PILA-CrossRef), USA. The institute is an institutional signatory to the Budapest Open Access Initiative, Hungary advocating the open access of scientific and scholarly knowledge. The Institute is a registered content provider under Open Access Initiative Protocol for Metadata Harvesting (OAI-PMH).

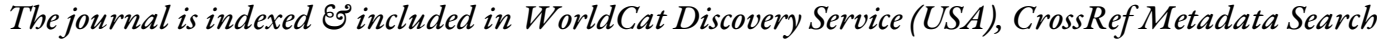
(USA), WorldCat (USA), OCLC (USA), Open J-Gate (India), EZB (Germany) Scilit (Switzerland), Airiti (China), Bielefeld Academic Search Engine (BASE) of Bielefeld University, Germany, PKP Index of Simon Fraser University, Canada. 


\begin{abstract}
The study area lies to the east of the Nile (Sharg Elneel), Khartoum State (latitudes $15^{\circ} 25^{\prime \prime} 1^{\prime}$ and $16^{\circ} 19^{\prime \prime} 1^{\prime} \mathrm{N}$ and longitudes $33^{\circ} 19^{\prime \prime} 8^{\prime}$ and $33^{\circ} 02^{\prime \prime} 9^{\prime}$ E). Using remote sensing techniques and geographic information system (GIS), the changes in land cover/land use have been estimated using two methods: supervised and unsupervised classification. the images were those of the years 1973, 2001, and 2015 MSS, ETM, ETM+, respectively(173/49 \& 173/48 path/ row). The study area was classified into the following nine LU/LC types: water bodies, vegetation, rocky area, sandy soil, sandy sheet, clayey soil, bare soil, sand dunes and settlement areas. The individual areas covered by each type of land use/ land cover were calculated for each image using supervised and unsupervised classification. Then the areas were compared among the different years (images). The results indicated a decrease in areas of sandy soil, water bodies, vegetation cover, sand dunes, clay soil, and bare soil for years 1973-2001 and 1973-2015. That was associated with significant increase in settlement area, sand sheet for the same period. As for the period 2001 and 2015 was an increase in the areas of vegetation, sandy soil, dunes, clay soil, and settlement. While there was a decrease in water bodies, rocky area, sand sheet and bar soil. A striking result of his study was an increase of 50\% in the settlement area for the period 1973 - 2015. This indicated that more drift of people towards the Capital took place during this period possibly due to drought and civil strife. Also people come to Khartoum to have better living conditions, education, health care and to work and may be they look at Khartoum as a spring board for going abroad. This study recommended the use of remote sensing techniques and geographic information system in the follow up of desertification and land degradation by following changes in land cover and land use. It also recommended that sand movement (sand encroachment) shall be retarded possibly through increasing vegetation cover through seed broadcasting of pasture and range plants during the rainy season and to exploit the ground water of the NSS aquifer for irrigation.
\end{abstract}

\title{
1. INTRODUCTION
}

Land is one of the most important natural resource, since life and development activities are based on it. Land is one of our most precious assets, it provides food, filters and stores water; and it is the basis for urban and industrial development, leisure, and wide range of social and economic activities. Land is a production factor because of the vegetation and crops that can be grown on it. The Land is threatened by degradation and desertification, mainly as a result of human activities and climate changes. This will, eventually, lead to some changes in the land use/ land cover. Digital change detection is the process that helps in determining the changes associated with land use and land cover properties with reference to geo-registered multi temporal remote sensing data. Land use refers to the type of utilization to which man has put the land. It also refers to evaluation of the land with respect to various natural characteristics. But land cover describes the vegetal attributes of land. The term land cover originally referred to the kind and state of vegetation, such as forest or grass cover, but it has broadened in subsequent usage to include human structures such as building or pavement and other features of natural environment, such as soil type, biodiversity, and surface and groundwater (Meyer, 1995). Digital change detection is the process that helps in determining the changes associated with land use land cover properties with reference to geo-registered multi temporal remote sensing data. Change detection is the process of differences in the state of an object or phenomenon by observing it at different times (singh, 1989). Change detection is an important process in monitoring and managing natural resources and urban development because it provides quantitative analysis of the spatial distribution of the population of interest. Change detection is useful in such diverse applications as land use change analysis, monitoring, shifting, cultivation, assessment of deforestation and desertification, study of change in vegetation phonology, seasonal changes in pasture production, damage assessment, crop stress detection, disaster monitoring, day/night analysis of thermal characteristics as well as other environmental changes(singh, 1989). Land use/land cover (LULC) changes play a major role in the study of global change. Land cover changes and human natural modification have largely resulted in deforestation, biodiversity loss, global warming and increase of natural disaster.

In Sudan, vegetation cover/land use studies are not frequent and are often limited to kordofan, Khartoum, and north White Nile states. Even in these states the studies are scattered(Alhaja, (2014);Dafalla 2006, Elhag 2005\& 2011, Muzmmel, M 2013 ,Adam Elhaija 2006,Khairy)Therefore, this study aims at: (1) Identification changes in land use land cover in an area East of the Nile, Khartoum for the period 1973 to 2015, (2) Identification of whether there is significant land degradation (mainly desertification) or not, (3)establishment of a recent database about the land use and land cover in the study area in an attempt tofill the gaps in Khartoum State.

\section{MATERIAL AND METHDS}

The study area (East of the Nile- Khartoum State) is covered by Land-sat 8TM. It lies between (latitude $15^{\circ} 25^{\prime \prime} 1^{\prime}$ to $16^{\circ} 19^{\prime \prime} 1^{\prime}$ and longitude $33^{\circ} 19^{\prime} 8^{\prime}$ to $\left.33^{\circ} 02^{\prime} 9^{\prime}\right)$. The area covers 613332.48 hectares. Fig 1 depicts the location of the study area. 


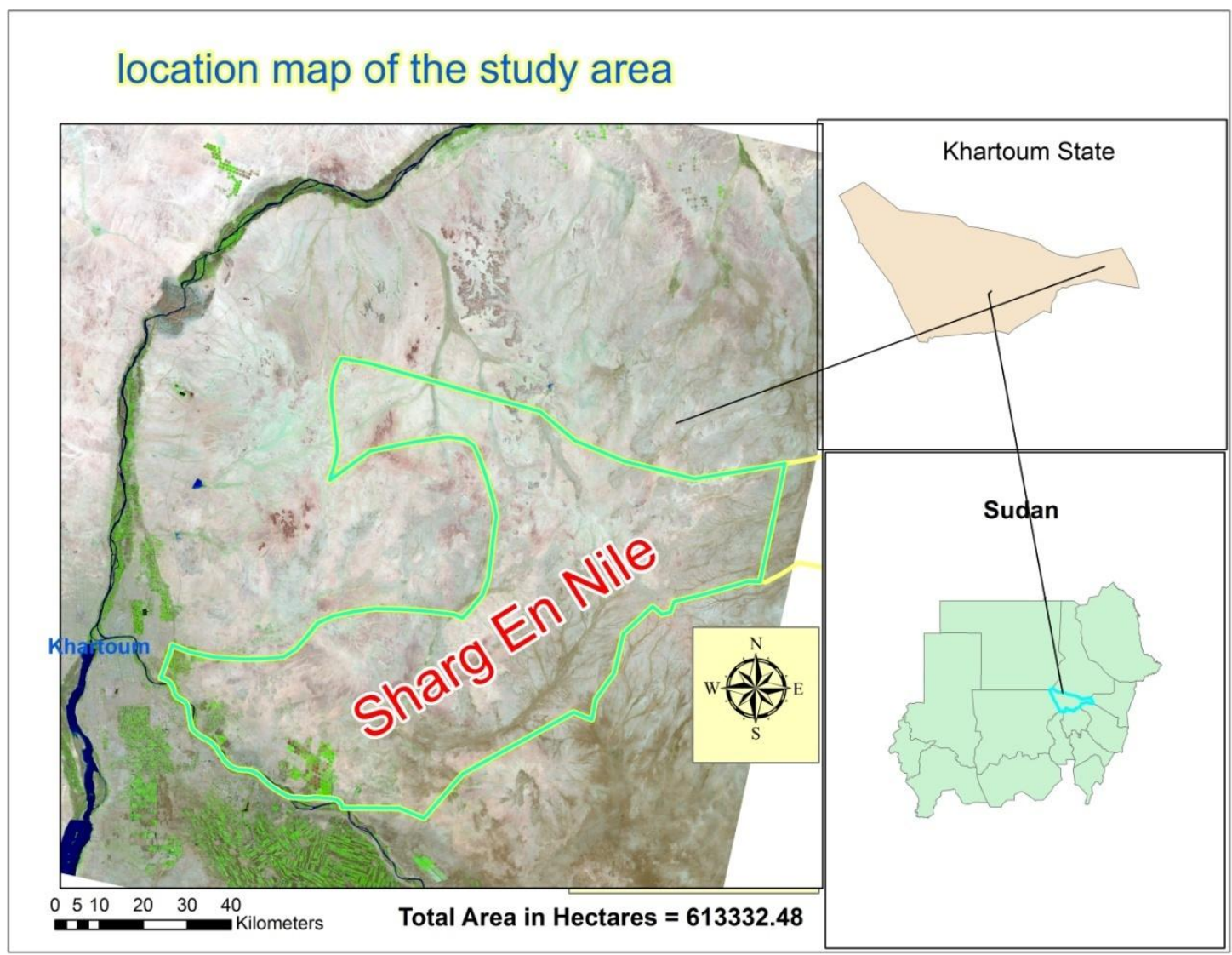

Figure 1:Location of study area (hargEn Nile- khartoum State)

According to (Van der kevie ,1976) the study area falls within semi desert and arid climatic zones (rains in summer and cool in winter). The topography and geology of the areaconsists of older alluvium, raised terraces, gravel and sand plains Umruwaba formation: gravel, sand, silt and clay (soil survey 2012). The naturalvegetation is very sparse and consisting mainly of sarieh( Maeruacrassifolia);-tundub $\underline{\text { Capparisdeciduas; }}$ seyal Acaciatortilis; Salam Acaciaehrenbergiana;mukheit Bosciaenegalensis and samur Acaciaradiana (plate1).

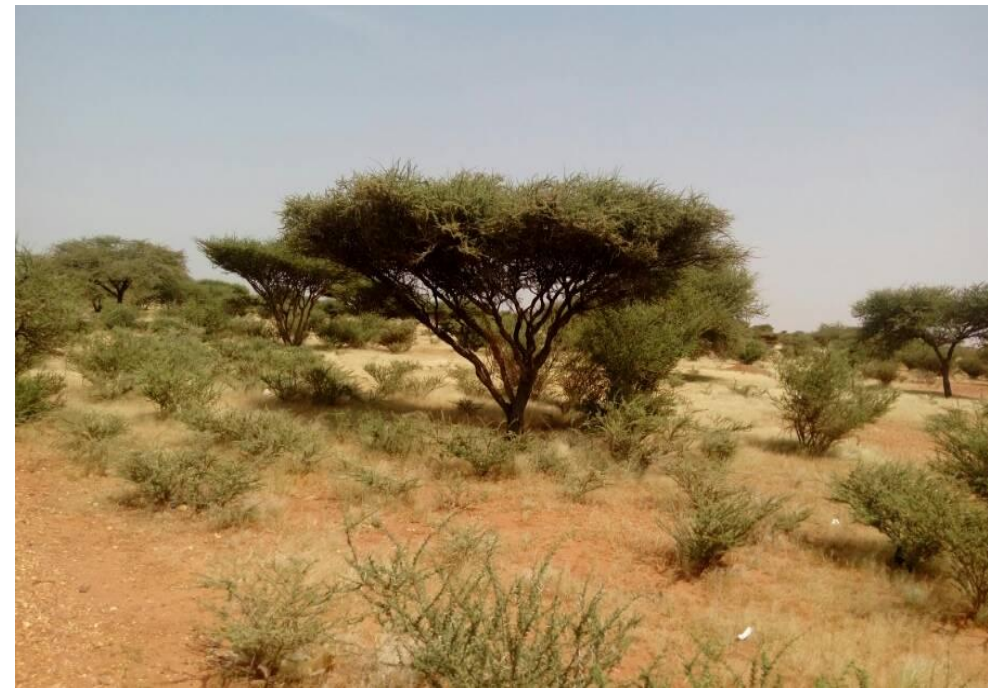

Plate1: some of the vegetation in the study area

The Study area is inhabitated by the tribes of hassaniah, Bataheen, alkwahla, and al kababesh. Most of them are pastoralist (plate 2) rearing goats, cows, camels and sheep. They are engaged in rain fed cultivation growing mainly sorghum. Small proportion of the population work in cities. 


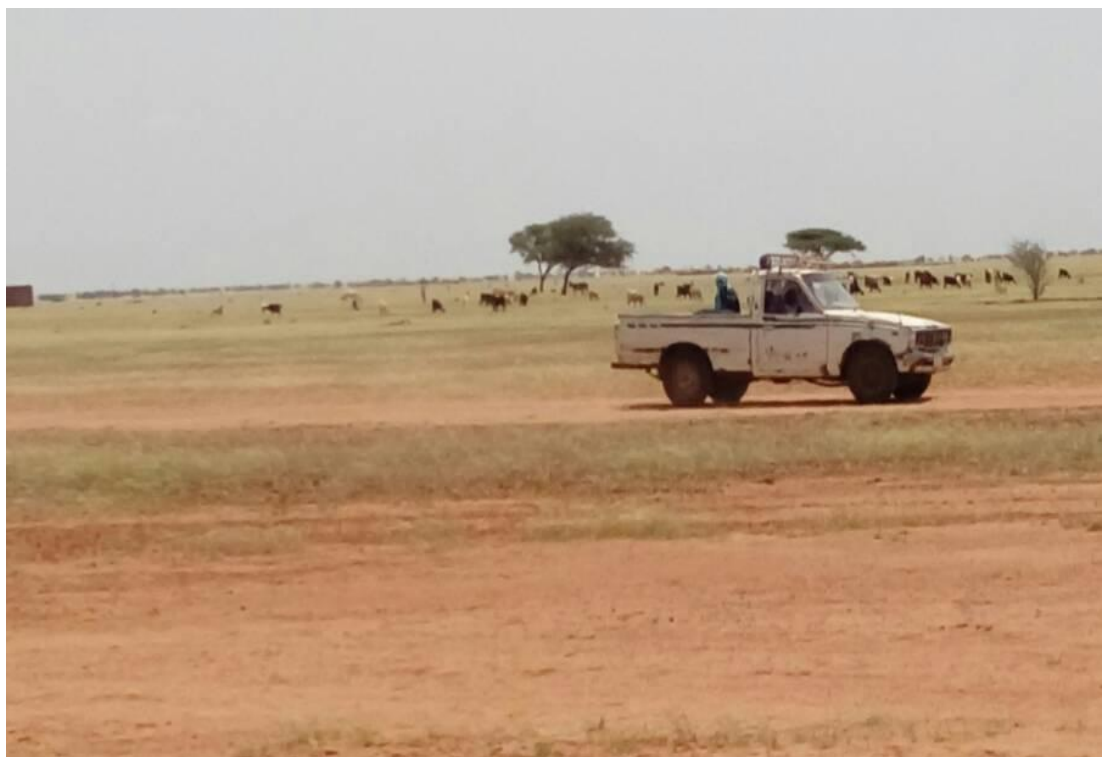

Plate2: Pastoralism in the study area.

The area is recharged from two main sources: direct percolation of rainwater (plate 3) and seepage through the khores and wadis seepage and seepage from the Blue Nile..The irrigated agriculture is limited and mostly depends on the Nile (soil survey 2012)

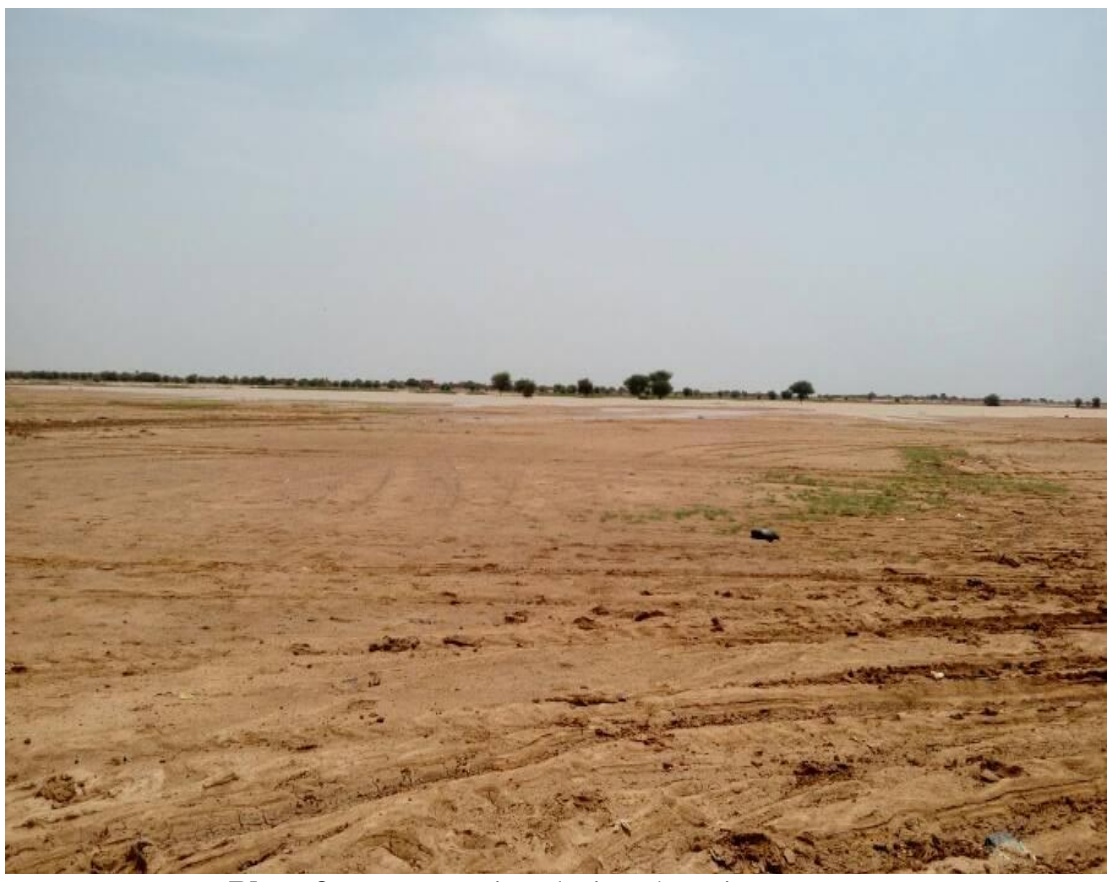

Plate 3:Water erosion during the rainy seasons

There are two types of soil which are according to t American System of Soil Classification (Keys to Soil Taxonomy, 2014). These are:Aridisols: Soils of the arid and semi-arid zones, andEntisols (Fluvents, Psamments): These are recent soils with no pedogenic horizons except of an ochric horizon.

In this study used three Landsat images (1973 -2001 -2015) covering the study area 613332.48hectares. Table 1 presents characteristics of these images

Table 1: Characteristic of satellite image used in this study

\begin{tabular}{|l|l|l|l|l|l|}
\hline Image & Path/row & Sensor & Band & Resolution & Date \\
\hline 1 & $173 / 49$ & MSS & $4,3,2$ & $80 \mathrm{~m}$ & 1973 \\
\hline 2 & $173 / 49$ & ETM & $4,3,2$ & $30 \mathrm{~m}$ & 2001 \\
\hline 3 & $173 / 49$ & ETM & $4,3,2$ & $30 \mathrm{~m}$ & 2015 \\
\hline
\end{tabular}


The hardware and software used in this study included: PC -intel(R) core ( TM ) I5-2450M CPU @ 2.50GH 2.50GH $\mathrm{GHAM}_{\mathrm{Z}}$ 4.00GB; Scanner -HP Deskjet 1510 series\Binlseries.exe" -Start UDC Device Page .size 2.16KB (2,212 bytes (size 4.00KB (4,096 bytes); Arc View (Advanced Spatial Analysis using Raster and Vector Data) was used for find production.- Microsoft word 2007 for word processing; color printer; -EARDAS imaging 8.5 -14 advanced software was used for image processing and analysis.

Remote sensing used in this study included: preprocessing; processing (image enhancement, visualization of multi band image and image classification).

A Geographical Information System (GIS) consisting of packages of computer programs was used for data capture, input, manipulation, transformation, visualization, combination, analyzing, query, and output.

Finally Arc Map view GIS software was used for a layout which allowed assemblage of all the components planned to appear on a map, arranged them together to get the needed design and then to be printed out when ready.

\section{RESULT AND DISCUSSION}

The results of visual interpretation and analysis of satellite images for the years 1973, 2001, 2015 in the study area including nine types of classes of land use/ land cover including: Water, vegetation, rocky area, sand soil, sand sheet, dunes, clay soil, bar soil and settlement. 
Table 4.1: The area of classes of LU/ LC and the difference between classes for these three years

\section{Result of satellite image for year 1973.}

Satellite image for year 1973 was classified to seven classes of LN/ LC: water body, vegetation, rocky area, sand soil, sand dune, clay soil, bare soil (Figure 2). Figure 3 shows the area in hectares of the individual LC/LU classes of the year 1973.

\begin{tabular}{|c|c|c|c|c|c|c|c|c|c|c|}
\hline Class & $\begin{array}{l}\text { Are } \\
a / h \\
a\end{array}$ & $\begin{array}{l}197 \\
3\end{array}$ & $\begin{array}{l}\text { Area/ha } \\
2001\end{array}$ & $\begin{array}{l}\text { Area/ha } \\
2015\end{array}$ & \begin{tabular}{|l} 
Different \\
in area \\
(ha) of \\
the image \\
$1973-$ \\
2001
\end{tabular} & $\begin{array}{l}\text { Different in } \\
\text { area/ha of } \\
\text { the image } \\
1973-2015\end{array}$ & $\begin{array}{l}\text { Different in } \\
\text { area/ha of } \\
\text { the image } \\
2001-2015\end{array}$ & $\begin{array}{l}\text { Different in } \\
\text { area } \\
\text { present of } \\
\text { the image } \\
1973-2001\end{array}$ & $\begin{array}{l}\text { Different in area } \\
\text { present of the } \\
\text { image } \\
\text { 2001-2015 }\end{array}$ & $\begin{array}{l}\text { Difference in area } \\
\% \text { of the image } \\
1973-2015\end{array}$ \\
\hline water & 2025 & & 818.91 & 721.8 & 1206.09 & 1206.09 & 97.11 & .28 & .01 & .02 \\
\hline $\begin{array}{l}\text { vegeta } \\
\text { tion }\end{array}$ & 48750 & & 12517.26 & 17341.92 & 36232.74 & 31408.08 & 4824.72 & 5.91 & .78 & 5.13 \\
\hline rocky & 14876 & & $\begin{array}{l}156619.7 \\
5\end{array}$ & 35224.29 & 141742.83 & 20347.37 & 121395.46 & 23.1 & 19.79 & 3.31 \\
\hline dune & $\begin{array}{l}23314 \\
2\end{array}$ & & 7127 & 15316.38 & 226013.32 & 217823.94 & 8189.38 & 36.852 & 1.33 & 35.522 \\
\hline $\begin{array}{l}\text { Sand } \\
\text { soil }\end{array}$ & 15860 & & 1632.7 & 29703.15 & 14227.46 & 13842.99 & 28090.45 & 2.33 & 4.59 & 2.26 \\
\hline $\begin{array}{l}\text { Sand } \\
\text { sheet }\end{array}$ & 0 & & $\begin{array}{l}163889.7 \\
1\end{array}$ & $\begin{array}{l}101523.1 \\
5\end{array}$ & 163889.71 & 101523.15 & 62366.65 & 26.72 & 10.07 & 16.56 \\
\hline $\begin{array}{l}\text { Clay } \\
\text { soil }\end{array}$ & 30150 & & 14798.05 & 21820.41 & 15352.36 & 8330 & 7052.36 & 2.51 & 1.15 & 1.27 \\
\hline $\begin{array}{l}\text { Bar } \\
\text { soil }\end{array}$ & $\begin{array}{l}26644 \\
3\end{array}$ & & $\begin{array}{l}158268.2 \\
1\end{array}$ & 47142.72 & 108173.52 & 219299.01 & 111425.49 & 17.64 & 18.11 & 35.75 \\
\hline $\begin{array}{l}\text { settle } \\
\text { ment }\end{array}$ & 0 & & 95586.06 & \begin{tabular}{|l}
342508.4 \\
1
\end{tabular} & 95586.06 & 342508.41 & 246922.35 & 15.58 & 40.26 & 55.84 \\
\hline
\end{tabular}




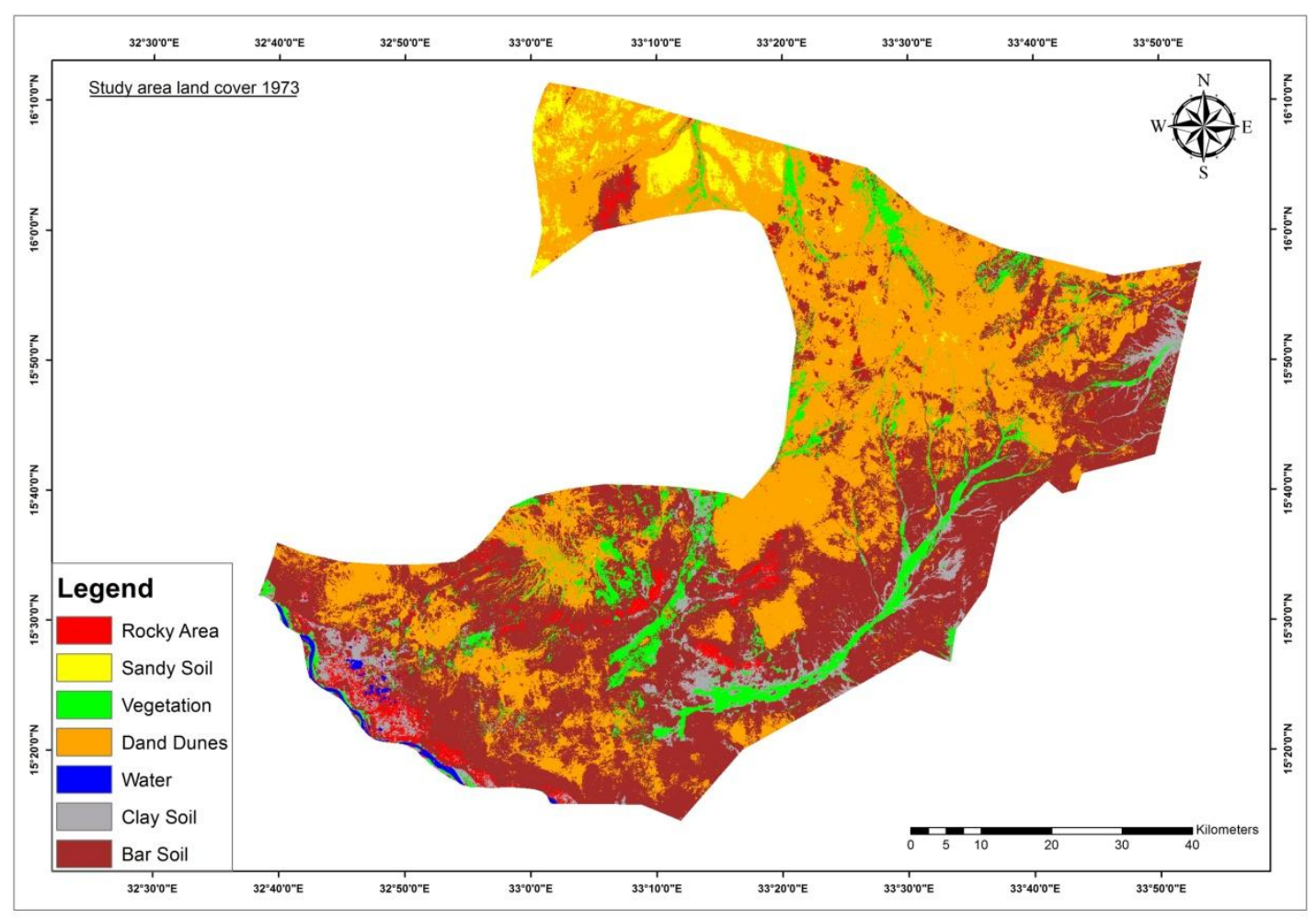

Figure2:Land use/ Land cover classes of the year 1973

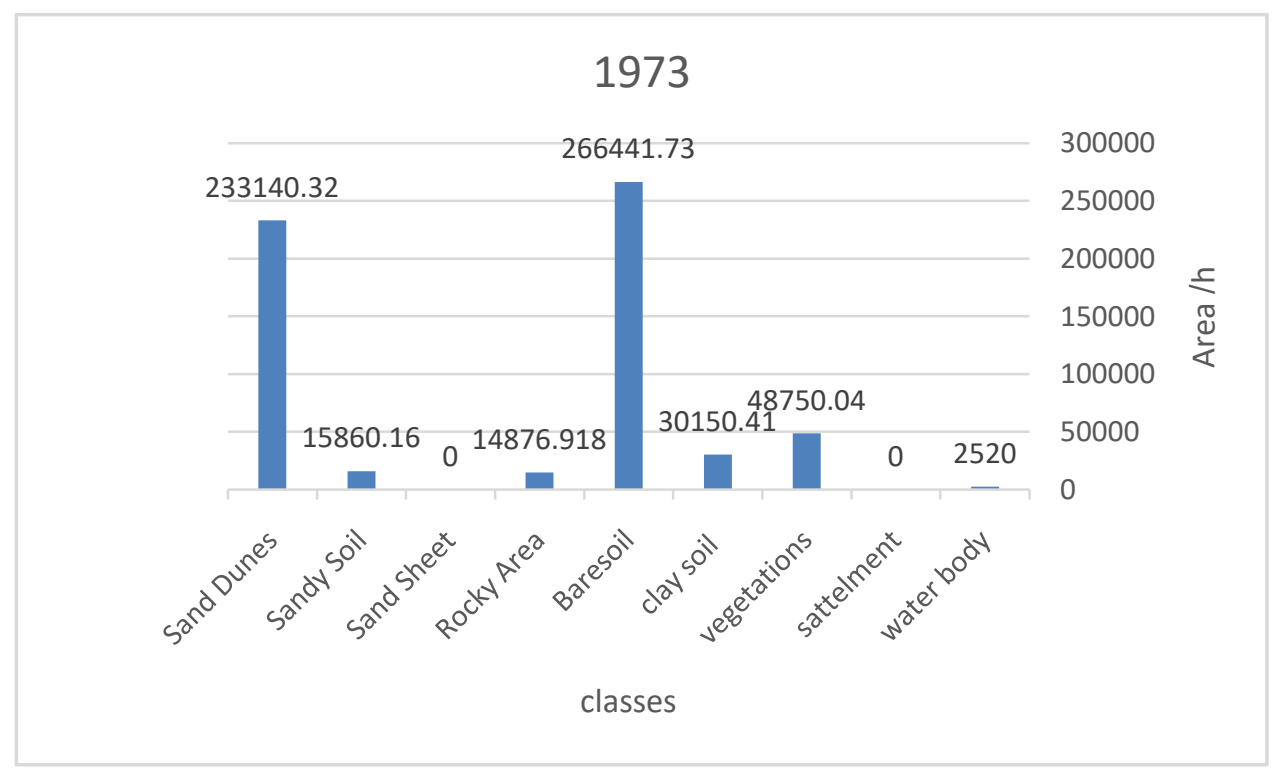

Figure 3: shows the area (hectares) of the individual LU/LC of the year 1973

The three most striking features of the classes of this year are:

1. Dominance of bare land(43.44\% of the total area)

2. Dominance of sand dunes (38.012\% of the total area)

3. Lack of residential area

This could be explained by the fact that the LU/LC of the year 1973 represents those of the period prior to the Great Drought of western Sudan (Darfur and Kordofan) that is everything was in equilibrium with the every moment. This was followed by the GREAT DROUGHT of the early seventies and eighties which has hit the Sudan and which has resulted in rustic changes in the LU/LC in the study area and else in the entire country which could be concluded from Figures 4.3 which shows LU/ LC in the study area in the year 2001 and Figure 4.4 which shows the area of each class in hectares. 


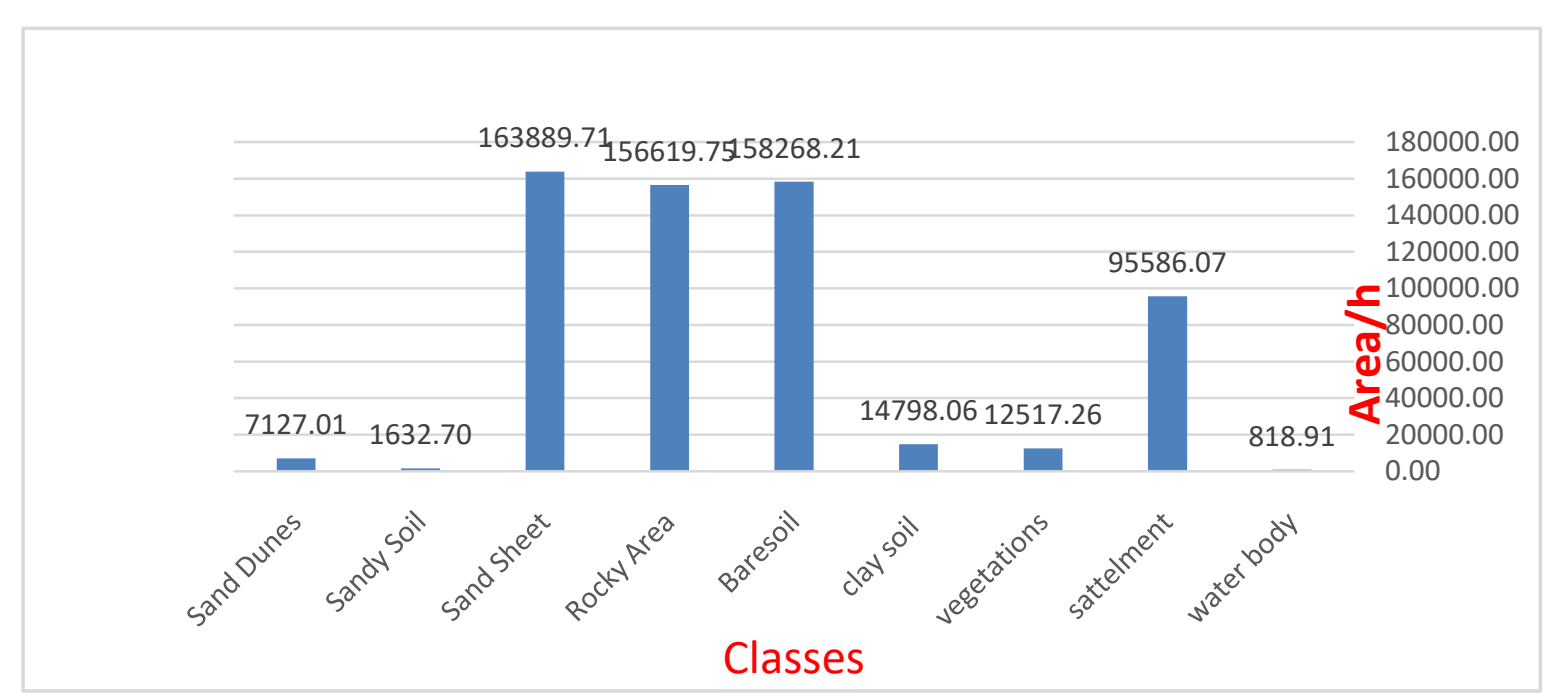

Fig 4: LC/ LU classes in the study area in the year 2001.

\section{Result of the satellite image of the year 2001.}

Nine types of classes of LU /LC classified for the satellite image for year 2001: water body, vegetation, rocky area, sand dune, sand soil, sand sheet, clay soil, bar soil, settlement (Figure 4)

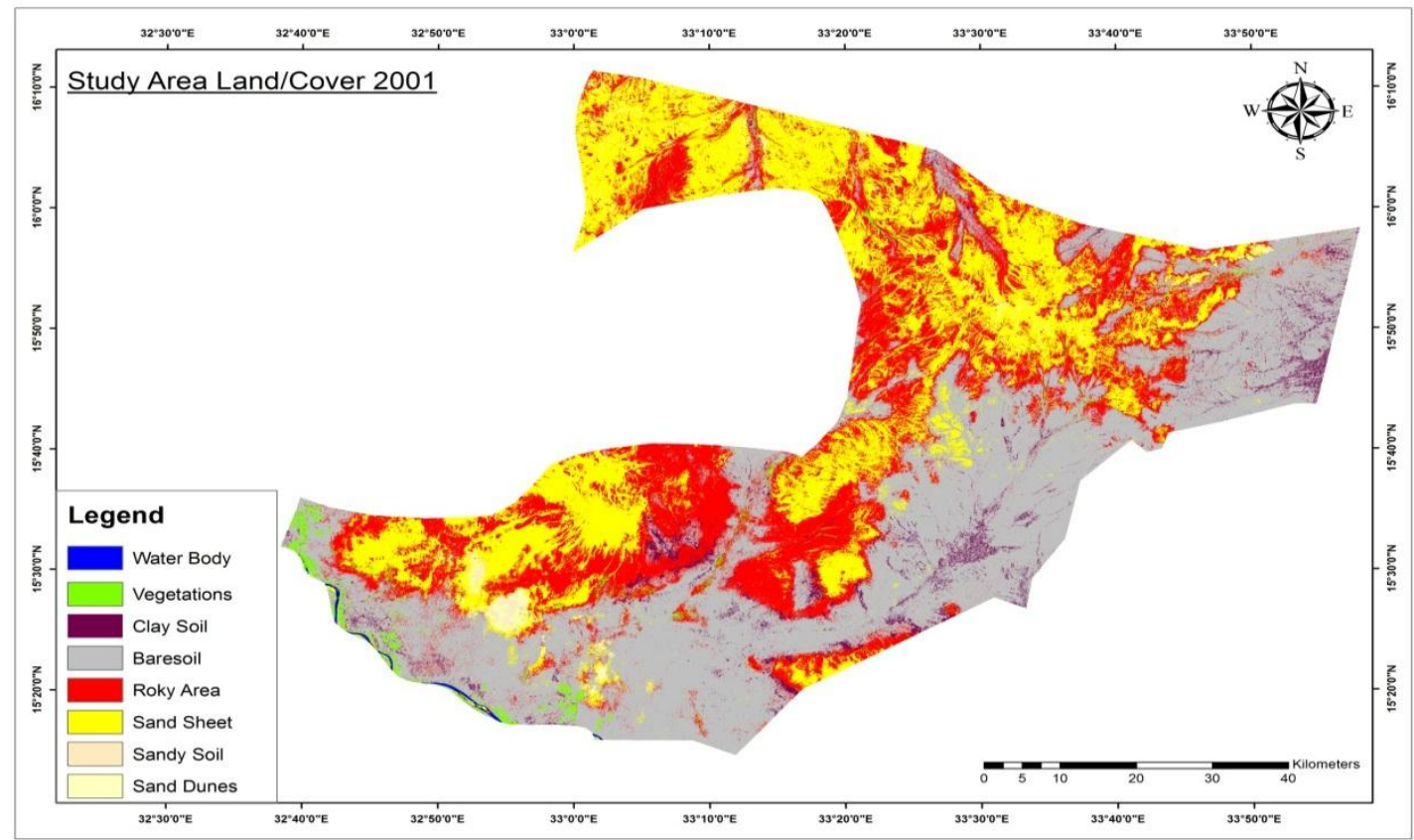

Figure 5: the area (hectares) of individual LU/ LC classes in the year 2001

The main features of the image of this year are:

1. Dominates of sand sheets $(26.72 \%)$, Rocky area $(25.53 \%)$, and bare soil $(25.8 \%)$.

2. Appearance of settlement area(15.58\%).

3. Almost disappearance of sand dunes(38.012\% in1973 to $2.49 \% 2015)$

4. Almost disappearance of sandy soil $(0.26 \%)$.

The dominance sand sheet together with rocky areas and bar soils and the almost disappearance sand soil indicates blowing of the sand by the strong winds that prevailed during the drought years. That is sand creeping has resulted in sand dunes and sandy soils spreading thin in form of sand sheets. On the other hand the appearance of settlement area $(15.58 \% \%$ of the total area indicated a massive drift of tribesmen from the drought hard hit areas towards the capital shows characteristic to that period. 
Result of satellite image for year 2015.

According to visual interpretation and analysis of satellite image for year 2015; the study area classified to nine classes of LU/ LC: water body, vegetation, rocky area, sand soil, sand dune, sand sheet, clay soil, bar soil, settlement.

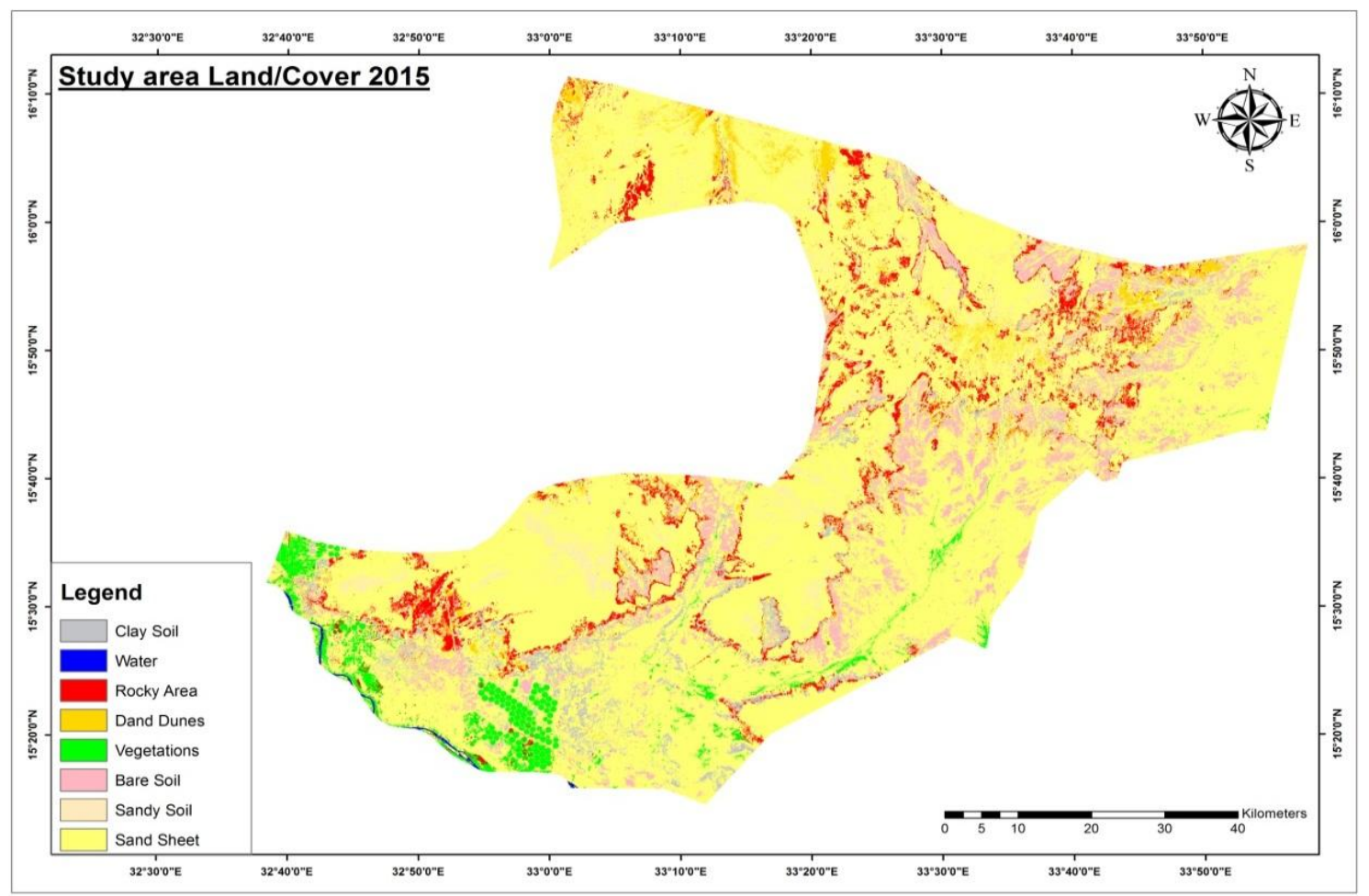

Figure 6: LU/ LC class in the study area in the year 2015

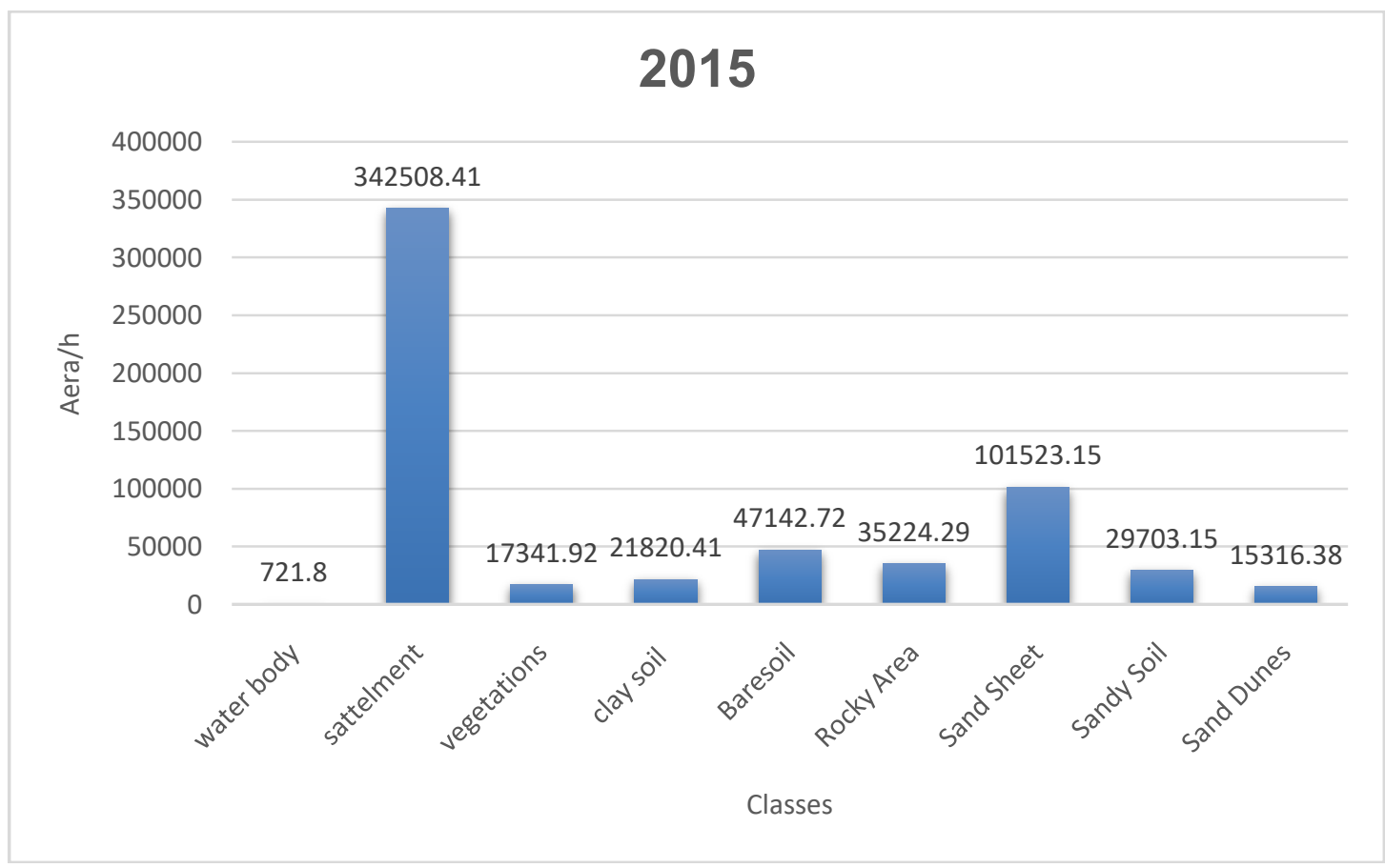

Figure 7: Shows the area (hectares) of the individual LC/ LU in the year 2015.

The main features of the image of this year are:

1. The main dominant class in this year is the settlement class (56\% of in the total area). 
2. Presence of sand sheet which were less extensive than in $2001(26.72 \%$ in 2001 and $16.56 \%$ in 2015).

3. Disappearance of rocky area $(5.74 \%)$ of in the total area.

Fig, 8 summarizes the result of the areas occupied by the 4 most changing LU/LC classes (settlement area, sand dunes, sand sheets and rocky area) during the period 1973-2015. The dominance of settlement (56\% of the total area) could be explained by the fact that people were still escaping drought and moving towards the capital ad big towns. Also the fact that sand sheets became the second dominant class indicated that desertification was still occurring but dominated by settlement activity. The continuous decline in the area occupied by sand dunes could be explained by the fact that these dunes had spread thin as evidenced by increase in the area of sand sheets; and the disappearance of Rocky area could as well be explained by the fact that this area was covered with sand encroachment.

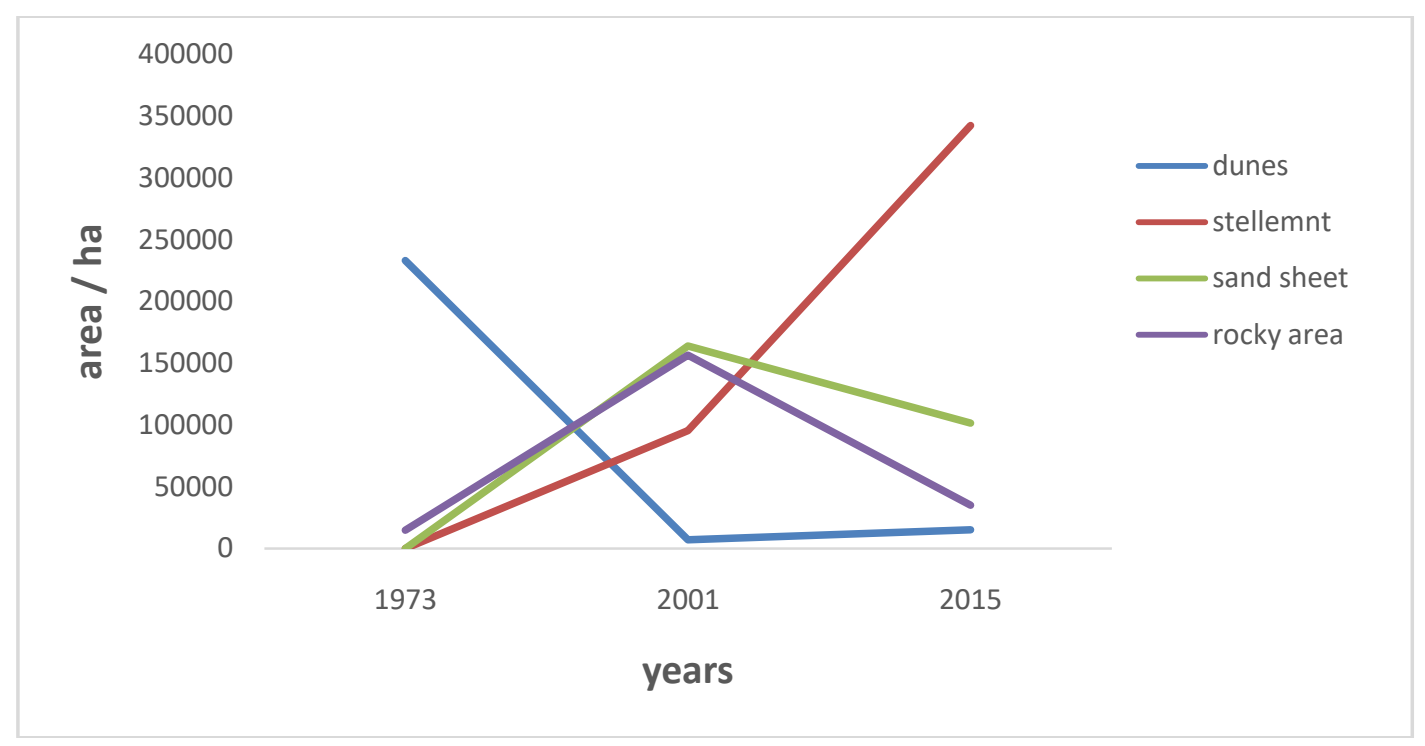

Figure 8: shows the area (ha) of the individual LU/ LC classes (settlement area, sand dunes, sand sheet, rocky area) during the period $1973-2015$

\section{RECOMMENDATION}

The study area is witnessing a significant deterioration of land, and shows through the field visit that the main cause of deterioration is wind erosion and overgrazing, so this study recommends:

1. Wind break to reduce erosion.

2. Broadcasting of seeds pasture plants in the rainy seasons to help in sand fixation.

3. Raising environmental awareness of the population.

4. There are areas where precipitation has been deposited in large quantities it is recommended that water harvesting be carried out for agricultural use.

\section{References}

[1] Alhaja, M. E (2014). Assessment of Sand Encroachment in the White Nile State, Sudan using Remote Sensing and GIS Techniques.409.

[2] Singh, A., (1989). Digital change detection techniques using remotely- sensed data. International Journal Remote Sensing, 10 (6): 989-1003.

[3] Soil Survey Staff. (2014). Keys to soil taxonomy. United States Department of Agriculture Natural Resources Conservation Service.

[4] Dept. of Soil and Environment Science Staff(2012) Semi Details Soil Survey and Land Evaluation of the Soil of Khartoum State. Part 2 East of the Blue Nile (Sharg El-Elneel).

[5] Van der kevie, (1976). Climatic Zones in Sudan. Soil Survey Administration.

[6] Adam H. E (2010). Integration of Remote Sensing and GIS in Studying Vegetation Trends and Conditions in the Gum Arabic Belt in North Kordofan, Sudan. PhD Thesis. Institute of Photogrammetry and Remote Sensing, TU Dresden, Germany

[7] Dafalla, M.S (2006). Mapping and Assessment of Land Use/Land Cover Using Remote Sensing and GIS in North Kordofan State, Sudan, PHD thesis, Dresden. Germany. 
[8] El Haja, M.E., (2006). Study of Desertification Based Upon Remote Sensing and GIS Techniques (Khor Abu Hbil Area). M.Sc. Thesis. U of Kordofan, Sudan.

[9] El Hag, A. M. (2005). Assessment of Desertifications in El Dongola area using Remote Sensing and GIS. M.Sc Thesis. University of Khartoum, Sudan

[10] El Hag, A. M. (2011). Assessment of Land Degradation in El Tahameid Group, Sudan, Using Remote Sensing and GIS. Phd Thesis. Sudan Academy of Science (SAS).

[11] Muzmmel, M (2013). Spatial Variability and Land Evaluation of the Soils of Almanagil Ridge, Elgazira State, Sudan Aided by Remote Sensing, GIS and Other techniques.. Phd Thesis. U of K, Sudan. 